\title{
An assessment of primary school pupils' needs with regard to planning the social- pedagogic interventions - standardisation of the measurement instrument
}

\author{
Dejana Bouillet \\ University of Zagreb, Faculty of Teacher Education
}

Abstract

This paper presents the development process of the measuring instrument for timely identification of elementary school pupils' behavioural problems, with the aim of proper implementation of appropriate socio-pedagogical interventions. ${ }^{1}$ The key matter discussed in the paper is the Questionnaire for assessment of interventional needs of pupils - version for pupils, which is being developed and evaluated with the aim of contributing to the standardisation and evaluation processes of the socio-pedagogical interventions in elementary schools. ${ }^{2}$ The research was conducted on a sample of 3301 pupils from the third, fifth, and seventh grades, from 43 elementary schools in 13 Croatian counties. The final version of the Questionnaire consists of 42 variables which measure relationships with peers, relationship towards education, relationship towards obligations, relationships with parents, the level of parental support, openness in communication and interests, relationships with teachers, self-satisfaction and permissiveness in upbringing. The reliability, validity and objectivity of the Questionnaire are satisfactory (Cronbach's Alpha $=.894$ ). The pupils were clustered in three groups, based on the result on the Questionnaire: pupils with behavioural disorders, with behavioural difficulties and other pupils who do not display behavioral difficulties or disorders. It was found that, according to this criteria, there is an average of $12.88 \%$ pupils with behavioural problems in Croatian elementary schools.

This paper suggests guidelines for grouping pupils into categories that depend on the gender and age of the pupils, but the precise norms concerning the criteria will be developed in the next stage of the project.

Keywords: pupils with behavioural disorders, early identification, standardisation of measure instrument, socio-pedagogical interventions in elementary school

\section{Introduction}

Pupils' behavioral problems are among the most common special educational needs that also produce an unfavorable effect on the pupils' educational attainment and social development. These are pupils whose behaviors are not in line with the usual age-appropriate behaviors, the situation they find themselves in, or the cultural and social norms of the school, the family, or their broader environment. These behaviors also have negative consequences for the pupils themselves and for their environment, making it difficult for these children to successfully socially integrate. These behaviors are also linked to various consequences and states that are the object of the need to guide, alter and/or resolve the behaviours, necessitating the involvement of various experts from various field. The Standards of terminology, definition, criteria, and the means of following the

1 The measurement instrument was developed as part of the Development of models of socio-pedagogic interventions in elementary school which has been conducted with the support of Croatian Agency for education in 2015.

2 During the research process, the questionnaire was referred to as the Pupils' socio-pedagogic needs assessment questionnaire, in order to avoid the potential for any stigmatization of the respondents. 
appearance of behavioural disorders in children and youths (Koller-Trbović, Žižak, Jeđud Borić, 2011), states that this group of behavioural problems comprises risk behaviors, behavioral difficulties, and behavioral disorders. In a sample of 921 younger elementary school pupils from 6 Croatian schools who have manifested behavioral problems, Pavin Ivanec (2015) has found that some of the behavioral problems (inclusive of risk behaviors) are exhibited by $20 \%$ of pupils in the $7-10$ age group. Pastor, Reuber, and Duran (2012), using a representative sample of 4-17 year-olds in the United States, find that behavioral problems, as tested by the Capabilities and Difficulties Questionnaire, are had by $7 \%$ of the children. Abu-Rayya and Yang (2012) also estimate that the risk for developing serious behavioral disorders in Australian children under the age of 15 is $7.6 \%$. Nevertheless, the data on the prevalence of the problems in primary school childrens' behavior vary from one study to the next, with the estimates ranging from 3.5 to $32.3 \%$, depending on the criteria that are used (Conley, Marchant and Caldarella, 2014). The teachers' reporting places the estimate at an average of three pupils with behavioral problems in each classroom (Conroy and Brown, 2004).

Simultaneously, the literature finds a general consensus concerning the unfavorable consequences of the behavioral problems on the learning and socialization outcomes (Gable, 2004; Boydell, Brauner and Bowers Stephens, 2006; Barnett, 2011). Those pupils who manifest behavioral problems in the early stages of education are at a greater risk of academic failure, dropping out, rejection by peers, substance addiction, and involvement in juvenile delinquency (Eklund et al., 2009). Additionally, a significant correlation has been found between the early childhood behavioral problems and behavioral problems in adolescence (Conroy and Brown, 2004). The literature has also documented the complexity and instability of children and youths' behavioral problems (Koller-Trbović and Žižak, 2012), which thus prompt complex and interdisciplinary responses from the professionals and the society.

There are several professions that deal with the pupils with behavioral problems, and this paper focuses on the work of social pedagogues in particular, ${ }^{3}$ which is defined as a visible intervention in the lives of children and youths, with the aim of encouraging their development, participation in social life, and learning (Storø, 2013). Storø also understands social pedagogy as a concept of work with young persons who are dealing with various problems in their daily circumstances, based on specific practical, theoretical, and scientific concepts. Kyriacou et al. (2009) define social pedagogy in the practical sense as a set of actions undertaken by adults with the aim of promoting personal development, social education, and general welfare of the child, conducted in a wide range of educational and social settings (preschool, school, family, institutions that care for children and youths, youth clubs, state institutions, and other). Stevens (2010) defines it as a set of social actions contained in the educational practice aimed at preventing or ameliorating the social problems of children and youths, and acting to encourage positive changes in the behavior and the conditions of their growth and development. This is a holistic and personalized approach to children and youths that binds the education and the social care for children, and includes work with the individual and their social surroundings (family, school, peer groups, wider community), with the end-goal of affirming children's rights.

In the educational context, social pedagogy can be described as an integrated approach to the needs of the children, with a particular emphasis on the five key dimensions: care, inclusion,

3 The term is referring to all genders. 
socialization, educational support, and social education (Kyriacou, 2009). Social pedagogy in the educational settings thus offers an integrated conceptual basis for the development of children's social welfare promotion, using the social-pedagogic methods and strategies (Smith and Whyte, 2008) which include pedagogic, social, correctional, and therapeutic areas of engagement (Žižak, 2010). Some examples of social-pedagogic interventions in the school environment include individual counseling, assuring assistance by peers and mentoring, children's participation in the workshops for developing communication and social skills, strengthening of self-confidence and organizational skills, understanding of family relationships (e.g. I as an Important Link, My Place in the Family, Communication - Parent - Child, When I am a Parent I Will...), and others. The social-pedagogic interventions directed at parents and teachers are also conducted in the form of individual or group work, such as conversations and workshops that aim to strengthen educational potential, encourage better quality of relationships with the child/pupil, development of educational skills, and other (e.g. A Family is Not an Island, The Practice of Restitution, Needs and Wishes).

The proposed Framework for encouraging and adjusting the experience of learning, and the assessment of children and pupils experiencing difficulties (2016, a working version of the document created as part of the reform of the school curriculum in Croatia) notes that a social pedagogue, among other things, provides educational support to those pupils for whom there is a risk of developing behavioral problems, and designs and implements professional interventions for the pupils who have developed behavioral problems, all with the aim of their success in achieving the demands of their education and supporting their healthy development. To that end, he/she:

- Conducts an analysis of the pupils' needs, the behavioural problems, and the potential that stems from the pupils' own characteristics as well as their environment's characteristics

- Develops, implements, and assesses individual and group-based interventions, as founded on the assessment of needs and evidence of effectiveness

- Proposes various forms of support for pupils to the other participants in the educational process

- Implements advisory measures aimed at teachers, parents, and other important adults, with the aim of creating conditions that are favorable to the pupil's appropriate development

It is thus clear that social pedagogues are expected to implement theoretical and scientific findings that ensure the achievement of expected welfare of the users of social-pedagogic interventions, i.e. a transformation of the pupils' behavioral problems into socially acceptable and individually effective behaviors. This is an exceptionally demanding and complex process that is somewhat rarely implemented in practice, partly due to a pronounced multidimensionality of the behavioral problems' phenomenology and etiology, and partly due to the weaknesses in the system of interventions that have not been sufficiently differentiated and aimed at the specificities of individual users (Bouillet, 2011). The practice based on the indicators of success assumes the use of tried skills, techniques, and strategies in the immediate interaction of experts and users, which leads to the development of tested and effective programs in the shape of organized, multilayered, 
multidisciplinary interventions aimed at persons who are experiencing complex problems (Bouillet, 2015a). In short, this is a matter of planning practical work on the basis of known empirical findings that ensure the achievement of desired results. When it comes to social-pedagogic interventions, a practice based on the evidence of success depends on the needs of the pupils themselves, i.e. on the difficulties that were identified by the social pedagogue and the pupil herself as those that are most disruptive to her balanced social functioning. In that context, the aim of the assessment of the pupil with behavioral problems is to allow for the problem to be reduced or ameliorated through appropriate intervention, making it possible for positive changes, which allow every person optimal inclusion in the life of the community, to take place (Koller-Trbović, Mirosavljević, Jeđud Borić, 2013). In that regard, a variety of measurement instruments has been developed (KollerTrbović, Nikolić and Dugandžić, 2009; Žižak and Koller-Trbović, 2013, and others), but these are typically more appropriate for children and youths that are already taking part in some form of social-pedagogic treatment in the institutions specialized for working with children and youths that are exhibiting behavioral problems.

The social-pedagogic practice in primary schools requires that such measurement instruments are developed that would be sensitive to the needs of the pupils that are dealing with behavioral problems, and that would allow for their timely inclusion in the intervention, allowing for the planning of a context-appropriate intervention (i.e. the context of the educational establishment). Such a measurement instrument is aimed at a comprehensive assessment of the strengths and weaknesses of the child and her environment, and it builds on the provision of adequate support to the pupil in question and the persons vital to her development (parents, teachers, peers).

This paper traces the process of creation and standardization of precisely this sort of measurement instrument, aimed at the primary school pupils in Croatia, and named the Assessment of Pupils' Needs in the Area of Social-Pedagogic Intervention Questionnaire - Pupils' Version.

\section{The Research Context and Test Application of the Questionnaire}

The research that this paper is based on was conducted as part of the broader project on the Development of the Models of Social-Pedagogic Interventions in Primary School that has been conducted since September 2015 with the support of Croatia's Education and Teacher Training Agency, with the aim of developing a model of social-pedagogic intervention that would enable the best possible protection of the rights of primary school pupils who are experiencing behavioral problems, bearing in mind the prevalence and phenomenology of pupils' behavioral problems, their need for timely and professional identification, and the need for intervention that includes all relevant ecological systems and environments that the pupils function in (school, family, spare time, peer relationships, and other). The project was conceived as an expression of the need for the standardization of social-pedagogic practice in Croatian school, as expressed by the social pedagogues themselves, and with the aim of ensuring that all pupils who are dealing with behavioral problems fulfill their right to the development of their personalities, talents, and the full potential of their intellectual and physical abilities (UN Convention on the Rights of the Child, 1990) and the aim of contributing to the fulfillment of the Strategy for Education, Science, and Technology (2014) which foresees the implementation of a comprehensive system of support (in the educational institutions and outside them) for pupils who are experiencing difficulties. 
The project was initiated at the Conference on the Analysis of Needs and Possibilities of Early Social-Pedagogic Intervention, organized by the Education and Teacher Training Agency in September 2015. It was there that a team of professionals was formed to develop and lead the project. ${ }^{4}$ The team has developed the project with the following specific aims:

- To develop standardized procedures of timely and professional identification of pupils with behavioral problems

- To develop the models of social-pedagogic intervention which are in line with the identified behavioral problems

- To develop a system of measuring the effectiveness of the social-pedagogic interventions, with regard to the observed changes in the pupils' behavior and the ecological factors that reduce the risk of future manifestation of behavioral problems among the users of the intervention.

With the aim of developing the standardized procedures for timely inclusion of pupils in the social-pedagogic interventions, the members of the team have developed the Assessment of Pupils' Needs in the Area of Social-Pedagogic Intervention Questionnaire - Pupils' and Parents' Version. The questionnaires included a set of claims for self-assessment and assessment of the pupils' attitudes towards themselves, their family, head teacher, peers, obligations, property and the general surroundings. The claims were organized in seven scales, based on the area of assessment. Each scale comprised 25 items, with the exception of the scale for assessing family relations in the pupils' version because some of the items concerned the pupils' relationship with their mother, and some with their father, pushing the total number of items to 40 . The items were organized as five-point Likert items, with the score of 1 meaning "Not at all true", and 5 meaning "Completely true." The questionnaires were compiled in such a broad manner in order to comprehensively assess all areas of social-pedagogic interventions in the school environment, and they comprised sets of balanced items.

Both versions of the questionnaire were tested in pilot application in primary schools where members of the team are employed, with the pupils' version we discuss in this paper tested on samples of students in the third, fifth, and the seventh grade. The parents gave written consent for their children's participation in the study. These groups of students were chosen because of the developmental features of mid-childhood and early adolescence, as well as because of the need to gain an insight into the possible effects of transition from general to subject-based instruction to the pupils' needs and behaviors.

The study was conducted by social pedagogues during class administration sessions, providing appropriate information and guidance to both the pupils and the parents, at the end of the first semester of the 2015/2016 school year. The questionnaires had identification codes so that the pupils' anonymity can be preserved in the process of matching pupils and parents' questionnaires.

4 The leader of the team is Alma Rovis Brandić, mag. prof. soc. pead. (Education and Teacher Training Agency), and its members are as follows: Dejana Bouillet (Department of Education, University of Zagreb), associate Valentina Kranželić (Faculty of Education and Rehabilitation Sciences, University of Zagreb), Jelena Bićanić, prof. (Matko Laginja Primary School, Zagreb), Ana Ivančan, prof. (Ljudevit Modec Primary School, Križevci), Ljiljana Samardžić, prof. (Nikola Tesla Primary School and Prečko Primary School, Zagreb), Nevenka Kišak Gverić, prof. (Grigor Vitez Primary School, Zagreb), Marija Sitar, prof. (Matija Gubec Primary School, Zagreb) i Željka Gomuzak Anić, prof. (Velika Mlaka Primary School, Velika Mlaka), all of whom are professionals in social pedagogy. 
The pilot study encompassed 350 pupils (51.4\% male and $48.6 \%$ female), across 6 primary schools (Table 1). The pupils' average age is 10 years and 8 months.

Table 1 Sample structure, by school and the pupils' grade

\begin{tabular}{|l|c|c|c|c|}
\hline Primary School & 3rd grade & 5th grade & 7th grade & Total \\
\hline Grigor Vitez & $15(35,7 \%)$ & $19(45,2 \%)$ & $8(19,0 \%)$ & $42(100 \%)$ \\
\hline Ljudevit Modec & $23(11,3 \%)$ & $20(17,9 \%)$ & $22(7,2 \%)$ & $65(100 \%)$ \\
\hline Matija Gubec & $17(28,8 \%)$ & $21(35,6 \%)$ & $21(35,6 \%)$ & $59(100 \%)$ \\
\hline Matko Laginja & $15(46,9 \%)$ & $0(0,0 \%)$ & $17(53,1 \%)$ & $32(100 \%)$ \\
\hline Nikola Tesla & $20(48,8 \%)$ & $9(22,0 \%)$ & $12(29,3 \%)$ & $41(100 \%)$ \\
\hline Prečko & $23(39,7 \%)$ & $18(31,0 \%)$ & $17(29,3 \%)$ & $58(100 \%)$ \\
\hline Velika Mlaka & $20(37,7 \%)$ & $19(35,8 \%)$ & $14(26,4 \%)$ & $53(100 \%)$ \\
\hline TOTAL & $133(38,0 \%)$ & $106(30,3 \%)$ & $111(31,7 \%)$ & $350(100 \%)$ \\
\hline
\end{tabular}

The aim of conducting the pilot study was to allow for further work on standardizing the questionnaire and testing its measurement characteristics. The first step in the process of analyzing the data was the test of the items' variability, so that we could proceed to remove all items from the questionnaire that were not providing sufficient variation. In other words, the questionnaire was pared down to contain only those items which had at least $5 \%$ of the responses per response category. At this point, we were not testing for the normality of the distribution of responses, as the object of research is geared towards a minority of the pupils, meaning that excluding variables with a non-normal distribution could lead to the removal of items that are important for the assessment of their needs.

The second step of the analysis was to test the reliability of each individual scale. With that aim in mind, we calculated the total scores for the respondents on each of the scales and determined the Pearson correlation coefficient for each item and this total score. The questionnaire was to only keep those items that are statistically significantly $(p=.000)$ correlated with the total score on the scale. The third step was to test the reliability of the scale, by computing the Cronbach's Alpha coefficients. The results of these analysis can be found in Table 2.

Table 2 The number of items at the beginning and the number of those kept in the Questionnaire, and the corresponding Cronbach's Alpha coefficients.

\begin{tabular}{|c|c|c|c|c|}
\hline Scale & $\begin{array}{l}\text { Initial number } \\
\text { of items }\end{array}$ & $\begin{array}{l}\text { Items remaining } \\
\text { after the first stem }\end{array}$ & $\begin{array}{l}\text { Items remaining } \\
\text { after the second step }\end{array}$ & Cronbach's Alpha \\
\hline Attitude towards self & 25 & 21 & 16 & .608 \\
\hline Relationship with family & 40 & 17 & 14 & .798 \\
\hline Attitude towards head teacher & 25 & 12 & \multirow{2}{*}{21} & \multirow{2}{*}{.687} \\
\hline Attitude towards obligations & 25 & 13 & & \\
\hline Relationship with peers & 25 & 12 & 13 & .735 \\
\hline $\begin{array}{l}\text { Attitude towards property and } \\
\text { surroundings }\end{array}$ & 25 & 10 & 14 & .560 \\
\hline TOTAL & 165 & 85 & 78 & .839 \\
\hline
\end{tabular}

As the data in Table 2 demonstrate, the items on some of the scales did not pass the variablity test as they were poor at discriminating among respondents, with regard to the issue being 
measured. The items from those scales were placed into a single scale, so the final version of the questionnaire contains 5 scales (Attitude towards self, Attitude towards family, Attitude towards school, Attitude towards peers, Attitude towards property and surroundings). The Attitude towards school scale now contains items that used to comprise the Attitude towards head teacher and Attitude towards obligations scales.

\section{The aims, tasks, and hypotheses of this study}

The aim of the research project that followed the pilot study and the determining of the measurement characteristics of the developed instruments was to develop an instrument for timely identification of the behavioral problems among primary school pupils, in order to ensure the preconditions for the creation and evaluation of the social-pedagogic interventions in the school setting. These interventions are as follows: (a) standardized procedures of identifying pupils with behavioral problems and (b) determining the pupils' needs for social-pedagogic interventions. By developing these sorts of measurement instruments we aim to contribute to the development of practices based on indicators of success in social-pedagogic activity, as their content allows for following the changes in the tested areas of social-pedagogic interventions, i.e. measuring the pupils' needs before, during, and after involvement in various social-pedagogic and other interventions.

The following tasks stem from a thusly formulated research aim:

- Constructing a measurement instrument for assessing the primary school pupils' needs for social-pedagogic intervention, based on the pupils' self-assessment (Pupils' Needs in the Area of Social-Pedagogic Intervention Questionnaire - Pupils' Version)

- Determining the rules for identifying the pupils that are dealing with behavioral problems

- Testing these rules with regard to the pupils' age and sex

- Determining the proportion of pupils with behavioral problems in the population of primary school pupils in Croatia

The research is testing a general hypothesis that the Pupils' Needs in the Area of SocialPedagogic Intervention Questionnaire - Pupils' Version is appropriately differentiating between pupils with behavioral problems and those without, with the rules of assessment depending on the pupils sex and age. We also posit that the proportion of the pupils with behavioral problems will be similar to that found in previous research, i.e. up to 15\% (Bouillet, 2015b; Pavin Ivanec, 2015). Since risk behaviors primarily require a response from the family and other persons in the child's usual surroundings (e.g. teachers or pedagogues), the measurement instrument is aimed at identifying the pupils with behavioral difficulties and behavioral disorders. 


\section{Research Methods}

\section{Respondents}

The survey was conducted on a sample of 3301 pupils in the third, fifth, and seventh grades in 43 primary schools in Croatia. At least one class section from each of the grades, in each of the schools, took part in the survey.

The schools were selected from 13 counties, each of which was employing a social pedagogue, and agreed to take part in the project. ${ }^{5}$ Based on the data provided by the Croatian Bureau of Statistics, there are 860 primary schools in Croatia, and 199441 pupils in the third, fifth, and seventh grades (Statistical Bulletin: Primary Schools at the end of the 2014/2015 and beginning of 2015/2016 school year). The sample is thus made up of $5 \%$ of all Croatian primary schools, and $2.76 \%$ of all pupils in the third, fifth, and seventh grades. However, as social pedagogues are only employed in $15 \%$ of Croatian primary schools, our sample can only be defined as a convenience sample.

The sample consists of $50.6 \%$ male and $49.4 \%$ female pupils. Among these, $31.4 \%$ were in the third grade, $35.5 \%$ in the fifth grade, and $33.1 \%$ in the seventh grade. The average age of the pupils in the sample is 11 years and 2 months. A majority of pupils (59.2\%) achieved an A average grade in the prior school year, a third had a B grade average (32.2\%), 8.1\% had a C grade average. Fourteen pupils in the sample $(0.4 \%)$ had a grade average $D$, and two $(0.1 \%)$ had been held back.

In order to test the validity of the questionnaire, the social pedagogues had noted the existence of identified behavioral problems for each of the pupils in the sample. Based on that criterion alone, there are 2826 pupils ( $85.6 \%$ ) in the sample who are not exhibiting behavioral problems, and 475 (14.4\%) of those who do. This is in line with the known research on the prevalence of behavioral problems among the primary school pupils, if the pupils with exhibited behavioral problems are taken into account (i.e. excluding those exhibiting risk behaviors).

\section{Data collection and measurement instruments}

We had acquired written parental consent for participation in the survey for each of the respondents. The response rates varied from school to school, but the rate was above $90 \%$ in each of the schools. The information was acquired and entered into the database by the social pedagogues who had also volunteered to take part in the study, each of them working on the data related to the school they worked in. They received special training to apply the Questionnaire at the meeting of social pedagogues organized by the Teacher Training and Education Agency on the 23rd of February 2016 in Zagreb.

The appropriate level of information concerning the purpose of the study was achieved by presenting the study to the pupils in class administration periods, and to the parents in the parent-teacher meetings. For that purpose, a presentation was prepared for the social pedagogues to discuss in these meetings. The participants' anonymity was achieved by subsequent encoding of the questionnaires, based on predetermined codes for each of the participants.

5 The information on the participating schools is available by request from the authors, and is omitted here due to limitation of space. 
The pupils filled in the Pupils' Needs in the Area of Social-Pedagogic Intervention Questionnaire - Pupils' Version as amended based on the pilot study, and containing 78 items grouped into five scales. The pupils filled in the questionnaires during one class period ( $45 \mathrm{mins})$, under the guidance of the social pedagogue.

\section{Data Analysis}

The process of constructing the measurement instruments included a greater number of experts in social pedagogy, so that the final scales may satisfy the criterion of content validity. In order to determine its construct validity, we conducted a factor analysis of the questionnaire, using the principal components method. In order to maximize the differentiation of certain assumed aspects of the pupils' needs, we used the Varimax rotation. Determining criterion validity of the questionnaire was based on introducing an independent criterion, i.e. determining the behavioral problems by other methods, regardless of the score they achieved on the questionnaire. ${ }^{6}$ We also sought to determine the correlation of particular items with the total score on the Questionnaire. The reliability of the measurement instrument was tested using the Cronbach's Alpha coefficients, and sensitivity by means of testing the statistical significance of the differences among the pupils with and without behavioral problems in t-tests for independent samples, on factors extracted by factor analysis.

The rules were determined based on percentiles, i.e. the pupils' results on the individual questionnaire factors, with regard to their age and sex. These were subsequently tested in twostage cluster analysis, by calculating the Pearson correlation coefficient across the determined groups of pupils and the independently assessed behavioral problems, and conducting the t-test for independent samples.

\section{Results}

The aim of each measurement instrument is to use the lowest possible number of items to describe the respondent in terms of the characteristic that the questionnaire seeks to measure. We took a broad approach to constructing the Pupils' Needs in the Area of Social-Pedagogic Intervention Questionnaire - Pupils' Version, aiming to avoid oversights or neglect of some aspects of the issue of behavioral problems among primary school pupils, which led to the adoption of a large number of variables, a total of 78 . This made the reduction of their number the focus of further work on standardizing the questionnaire, with the key concern of maintaining the measurement characteristics of the instrument.

In the first step, we tested the items' distribution, based on measures of skewness and kurtosis, bearing in mind the acceptability criterion for normality as the -2 to 2 range of the coefficients (George and Mallery, 2010). Based on this criterion, we removed the item "My head teacher punishes me for no reason", as it had a skewness score of 2.498, and a kurtosis score of 5.579. After that exclusion, the Cronbach's Alpha coefficient for the remaining 77 items was .862 .

6 This is the already discussed direct observation by the social pedagogues, based on their experience working with the pupils in these schools and conducting social-pedagogic interventions in the schools. 
In the second step, we conducted a t-test for independent samples, sorting the pupils on the basis of the independent criterion, in order to ensure the sensitivity of the questionnaire to the object of measurement. The variables whose t-test of significance value was greater than 0.050 were excluded from the questionnaire (there were 7 of these, see Table 3). After their exclusion, Cronbach's Alpha coefficient increased to .871 , with the remaining 70 items.

Table 3 Questionnaire items that were excluded due to poor sensitivity to the criterion of pupils' behavioral problems (values and significance of the t-test)

\begin{tabular}{|l|c|c|}
\hline Item & T-test value & Significance level ( $\mathbf{p})$ \\
\hline I like to be alone when I am sad. & .776 & .378 \\
\hline I like being tidy. & 2.146 & .143 \\
\hline I am afraid of my head teacher. & .332 & .564 \\
\hline I have more things than I need. & .028 & .866 \\
\hline $\begin{array}{l}\text { When I want something that does not belong to me, I ask the person who owns } \\
\text { it if I may borrow it. }\end{array}$ & .012 & .914 \\
\hline I like buying various things. & 1.892 & .169 \\
\hline I know where the money is kept in my house. & .319 & .572 \\
\hline
\end{tabular}

In the next step, we calculated the total scores for all the pupils, for all the items on the Questionnaire, in order to test the statistical significance of the individual items' correlations with the total score. We tested the statistical significance by calculating the Pearson correlation coefficient. Conducting this step led to the exclusion of three items whose correlation had a statistical significance below .050. The following items were excluded: I often buy things I do not need (coeff. corr. $=.026$ ); I often think about material things (coeff. corr. $=.042$ ); and I find it difficult to give up something I want (coeff. corr. $=.028$ ). Removing these items led to the increase in the Cronbach's Alpha for the questionnaire to .881 , with a total of 67 included items.

After that, we conducted the factor analysis. Using the Guttman-Kaiser criterion, we found 17 factors which explained $53.15 \%$ of joint variance. The analysis of a scree plot diagram and content analysis of the extracted factors from the questionnaire as well as their interpretability were used to single out the items that did not position well on the factors. These were the items that had similar levels of factor saturation, which were not interpretable in a consistent manner, and whose maximal factor saturation was less than .40 (Tabachnik and Fidell, 2001).

In this step, we excluded a further 14 items, and the Cronbach's Alpha coefficient for the questionnaire remained the same (.881, for 53 items). The following items were excluded: I am self-assured and self-confident; I retreat from uncomfortable situations; I like to be the centre of attention; In my family, we resolve disagreements through conversation; I respect the school rules; I engage in extracurricular activities; It happens to me that I take somebody else's things without their knowing; When I have money, I like to spend it all; My peers have more things than I do; I like sharing my things with others; I regularly receive an allowance.

After this round of exclusion, we repeated the factor analysis with the remaining 53 items, and used the same criterion to exclude a further 11 items (I can remain calm even when I am angry; I like to argue; I learn from my mistakes; I take part in making important family decisions; My head teacher is mild and often relents in his/her decisions; Other pupils avoid me; It is important to 
Dejana Bouillet: An assessment of primary school pupils' needs with regard to planning the social-pedagogic...

me that my peers think well of me; I resolve disagreements with my peers in a peaceful manner; My friends can persuade me to do things I do not want to do; When I find something and I do not know who the owner is, I try to find the owner; I am persistent in getting things I want, but I also care about others in the process.).

The final factor analysis was conducted on 42 items. It resulted in 9 factors that explain $53.15 \%$ of joint variance (just as the first round, conducted on a much greater number of items). Cronbach's Alpha coefficient of internal consistency of the questionnaire is now .894. We determined that the necessary condition of factorization were satisfied (KMO $=.890$, Bartlett's specificity test $=35327.614, \mathrm{df}=1035, \mathrm{p}=.000)$. The values of characteristic roots, the proportions of explained variance, reliability, and structure of each of the factors are displayed in Table 4.

Table 4 The values of characteristic roots, proportion of explained variance, reliability and structure of factors of the Pupils' Needs in the Area of Social-Pedagogic Intervention Questionnaire - Pupils' Version

\begin{tabular}{|c|c|}
\hline FACTOR OF ASSESSMENT OF RELATIONSHIP WITH PEERS (1) & Coefficients \\
\hline I think that most pupils have a good opinion of me. & ,643 \\
\hline My friends listen to me when I have a problem. & 600 \\
\hline I spend time with my school friends even when we are not in school. &, 578 \\
\hline I trust my friends. & ,632 \\
\hline During recess, I spend time with many pupils. & ,604 \\
\hline I am happy with the number of friends that I have. &, 556 \\
\hline Other pupils are attentive to me. &, 597 \\
\hline Characteristic root & 8,703 \\
\hline Proportion of explained variance & 19,434 \\
\hline Cronbach's Alpha & ,762 \\
\hline \multicolumn{2}{|l|}{ FACTOR OF ASSESSMENT OF THE ATTITUDE TOWARDS EDUCATION (2) } \\
\hline My success in school matches my effort and abilities. & ,699 \\
\hline I often volunteer to answer the teacher's questions in class. &, 423 \\
\hline I am happy with my success in school. & ,727 \\
\hline I regularly study and do homework when I am home. & 618 \\
\hline I think my success in school reflects my effort well. & ,752 \\
\hline Characteristic root & 2,498 \\
\hline Proportion of explained variance & 5,945 \\
\hline Cronbach's Alpha & ,764 \\
\hline \multicolumn{2}{|l|}{ FACTOR OF ASSESSMENT OF THE ATTITUDE TOWARDS OBLIGATIONS (3) } \\
\hline I am happy going to school. & 457 \\
\hline I take part in household chores. & ,687 \\
\hline I keep my workspace clean, both at home and at school. & ,648 \\
\hline I am successful in organizing my time to study. & ,491 \\
\hline When my friends are arguing, I help them make peace. & 460 \\
\hline Characteristic root & 2,158 \\
\hline Proportion of explained variance & 5,207 \\
\hline Cronbach's Alpha & ,638 \\
\hline
\end{tabular}




\begin{tabular}{|c|c|}
\hline \multicolumn{2}{|l|}{ FACTOR OF ASSESSMENT OF THE RELATIONSHIP WITH PARENTS (4) } \\
\hline When I am not able to solve a problem by myself, I seek my mother's help. & ,616 \\
\hline I have no secrets from my mother. &, 645 \\
\hline I can openly talk to my mother about anything. & ,675 \\
\hline When I am not able to solve a problem by myself, I seek my father's help. & ,681 \\
\hline I have no secrets from my father. & ,700 \\
\hline I can openly talk to my father about anything. & ,781 \\
\hline Characteristic root & 1,926 \\
\hline Proportion of explained variance & 4,702 \\
\hline Cronbach's Alpha &, 677 \\
\hline \multicolumn{2}{|l|}{ FACTOR OF ASSESSMENT OF PARENTAL SUPPORT (5) } \\
\hline My mother stands by me even when I do something bad. & ,614 \\
\hline My mother understands me and accepts me even when I am doing something unacceptable. & 826 \\
\hline My father stands by me even when I do something bad. & ,603 \\
\hline My mother understands me and accepts me even when I am doing something unacceptable. & ,798 \\
\hline Characteristic root & 1,660 \\
\hline Proportion of explained variance & 4,124 \\
\hline Cronbach's Alpha & ,767 \\
\hline \multicolumn{2}{|l|}{ FACTOR OF ASSESSMENT OF OPENNESS IN COMMUNICATION AND INTERESTS (6) } \\
\hline I have no difficulty speaking in front of the class or a larger group of people. & ,495 \\
\hline I express my opinion even when it is different from the opinion of others. & ,639 \\
\hline I can state my opinion even when it is different from the opinion of the head teacher. &, 636 \\
\hline It is easy for me to ask questions to the head teacher during class. & ,606 \\
\hline I have many interests that are not related to school. &, 436 \\
\hline Characteristic root & 1,358 \\
\hline Proportion of explained variance & 3,911 \\
\hline Cronbach's Alpha &, 631 \\
\hline \multicolumn{2}{|l|}{ FACTOR OF ASSESSMENT OF THE ATTITUDE TOWARDS THE HEAD TEACHER (7) } \\
\hline When I am not able to solve a problem by myself, I ask for my head teacher's help. &, 406 \\
\hline I can talk to my head teacher whenever I need to. &, 594 \\
\hline I follow what my head teacher tells me to do without complaint. &, 538 \\
\hline I believe that my head teacher has a good opinion of me. & 609 \\
\hline Characteristic root & 1,873 \\
\hline Proportion of explained variance & 2,952 \\
\hline Cronbach's Alpha & 619 \\
\hline \multicolumn{2}{|l|}{ FACTOR OF ASSESSMENT OF ATTITUDE TO SELF (8) } \\
\hline I am proud of myself and my actions. &, 494 \\
\hline I am happy with myself as I am. &, 783 \\
\hline I am happy with my appearance. & ,767 \\
\hline Characteristic root & 1,260 \\
\hline Proportion of explained variance & 3,254 \\
\hline Cronbach's Alpha & ,660 \\
\hline FACTOR OF ASSESSMENT OF PERMISSIVE UPBRINGING (9) & \\
\hline
\end{tabular}


Dejana Bouillet: An assessment of primary school pupils' needs with regard to planning the social-pedagogic...

\begin{tabular}{|l|c|}
\hline My mother is mild and permissive towards me. &, 778 \\
\hline My father is mild and permissive towards me. &, 723 \\
\hline My head teacher is mild and permissive towards me. &, 667 \\
\hline Characteristic root & $\mathbf{1 , 1 9 3}$ \\
\hline Proportion of explained variance & 3,109 \\
\hline Cronbach's Alpha & $\mathbf{6 3 5}$ \\
\hline
\end{tabular}

As the data in Table 6 indicate, the initial broad categories of pupils' needs did become more specific in factor analysis, with the scale of attitude to self dividing into two factors (openness in communication and interests, and attitude to self), the attitude to school dividing into three factors (attitude to education, attitude to obligations, and attitude to head teacher), as did the scale of attitudes towards family (relationship with parents, level of parental support, permissiveness in upbringing). The attitude to peers scale remained as it was, and the items in the attitudes to property and attitudes to surroundings did not pass the tests of the metric characteristics of the questionnaire. Some items from the initial scales have changed their place. In sum, the formed factors satisfy the statistical criteria of reliability and the further analyses use the total scores that the pupils had on each of the factors.

Table 5 displays the descriptive statistics for the formed factors in the Questionnaire.

Table 5 Descriptive statistics of the factors in the Pupils' Needs in the Area of Social-Pedagogic Intervention Questionnaire - Pupils' Version

\begin{tabular}{|c|c|c|c|c|c|c|c|}
\hline Factor & Rank & Minimum & Maximum & Mean & $\begin{array}{l}\text { Standard } \\
\text { deviation }\end{array}$ & Skewness & Kurtosis \\
\hline Relationship with peers (1) & 28 & 7 & 35 & 29,45 & 4,30 & $-1,338$ & 2,591 \\
\hline Attitude towards education (2) & 20 & 5 & 25 & 20,33 & 3,75 &,- 898 &, 458 \\
\hline Attitude towards obligations (3) & 16 & 4 & 20 & 15,75 & 3,15 &,- 733 & 179 \\
\hline Relationship with parents (4) & 24 & 6 & 30 & 24,88 & 4,06 & $-1,031$ & 1,149 \\
\hline Level of parental support (5) & 16 & 4 & 20 & 15,79 & 3,65 &,- 853 & ,231 \\
\hline $\begin{array}{l}\text { Openness in communication and } \\
\text { interests (6) }\end{array}$ & 24 & 6 & 30 & 23,41 & 4,07 &,- 694 &, 527 \\
\hline $\begin{array}{l}\text { Relationship with the head } \\
\text { teacher (7) }\end{array}$ & 16 & 4 & 20 & 16,01 & 2,95 &,- 931 & 1,092 \\
\hline Attitude to self (8) & 12 & 3 & 15 & 12,88 & 2,19 & $-1,439$ & 2,394 \\
\hline Permissiveness in upbringing (9) & 12 & 3 & 15 & 11,39 & 2,63 &,- 591 &,- 100 \\
\hline
\end{tabular}

The t-test and the Pearson correlation determined that the groups of pupils, based on the independent criterion of behavioral problems, are statistically significantly different on all factors, and belonging to these groups also statistically significantly correlates with the factors (Table 6).

Table 6 Statistical significance of the t-test and Pearson correlation results for the factors in the Pupils' Needs in the Area of Social-Pedagogic Intervention Questionnaire - Pupils' Version

\begin{tabular}{|l|c|c|c|c|}
\hline Factor & T-test & Significance & Pearson coefficient & Significance \\
\hline Relationship with peers (1) & 16,941 &, 000 &, 078 &, 000 \\
\hline Attitude towards education (2) & 43,858 &, 000 &, 000 &, 028 \\
\hline Attitude towards obligations (3) & 14,880 & 000 &, 000 \\
\hline
\end{tabular}


Criminology \& Social Integration Journal Vol. 24 No. 22016

\begin{tabular}{|c|c|c|c|c|}
\hline Relationship with parents (4) & 23,531 & ,000 &, 095 & ,000 \\
\hline Level of parental support (5) & 15,427 & ,000 &, 042 & 019 \\
\hline Openness in communication and interests (6) & 16,715 & ,000 &, 067 & ,000 \\
\hline Attitude towards the head teacher (7) & 12,230 & ,000 &, 065 &, 000 \\
\hline Attitude to self (8) & 50,230 & ,000 & 105 & ,000 \\
\hline Permissiveness in upbringing (9) & 2,872 &, 000 &, 049 & ,009 \\
\hline
\end{tabular}

Based on the percentiles calculated for the whole sample and the sub-samples of the male and female respondents, and for the groups of third, fifth, and seventh grade pupils, we formed three categories of pupils. The three categories are as follows: pupils with behavioral disorders (first percentile group), pupils with behavioral difficulties (second percentile group), other pupils who do not display behavioral difficulties or disorders. The percentile groups are displayed in Table 7.

Table 7 Percentiles of the pupils scores on the Pupils' Needs in the Area of Social-Pedagogic Intervention Questionnaire - Pupils' Version factors

\begin{tabular}{|c|c|c|c|c|c|c|}
\hline \multicolumn{7}{|c|}{ Relationship with peers (1) } \\
\hline Percentiles & Total & $\mathbf{M}$ & $\mathbf{F}$ & 3rd grade & 5 th grade & 7th grade \\
\hline 5 & 21,0 & 21,0 & 21,0 & 21,25 & 21,0 & 21,0 \\
\hline 10 & 24,0 & 24,0 & 24,0 & 24,0 & 24,0 & 23,0 \\
\hline 25 & 27,0 & 27,0 & 28,0 & 27,0 & 28,0 & 27,0 \\
\hline 50 & 30,0 & 30,0 & 31,0 & 30,0 & 31,0 & 30,0 \\
\hline 75 & 33,0 & 32,0 & 33,0 & 33,0 & 33,0 & 32,0 \\
\hline 90 & 34,0 & 34,0 & 34,0 & 35,0 & 34,0 & 34,0 \\
\hline 95 & 35,0 & 35,0 & 35,0 & 35,0 & 35,0 & 34,0 \\
\hline \multicolumn{7}{|c|}{ Attitude towards education (2) } \\
\hline Percentiles & Total & M & $\mathbf{F}$ & 3rd grade & 5 th grade & 7th grade \\
\hline 5 & 13,0 & 13,0 & 14,0 & 16,0 & 14,0 & 12,0 \\
\hline 10 & 15,0 & 15,0 & 16,0 & 17,0 & 16,0 & 13,0 \\
\hline 25 & 18,0 & 18,0 & 19,0 & 19,0 & 19,0 & 17,0 \\
\hline 50 & 21,0 & 21,0 & 22,0 & 22,0 & 22,0 & 20,0 \\
\hline 75 & 23,0 & 23,0 & 24,0 & 24,0 & 24,0 & 23,0 \\
\hline 90 & 25,0 & 25,0 & 25,0 & 25,0 & 25,0 & 24,0 \\
\hline 95 & 25,0 & 25,0 & 25,0 & 25,0 & 25,0 & 25,0 \\
\hline \multicolumn{7}{|c|}{ Attitude towards obligations (3) } \\
\hline Percentiles & Total & M & $\mathbf{F}$ & 3rd grade & 5 th grade & 7th grade \\
\hline 5 & 10,0 & 9,0 & 11,0 & 10,0 & 11,0 & 9,0 \\
\hline 10 & 11,0 & 11,0 & 12,0 & 12,0 & 12,0 & 11,0 \\
\hline 25 & 14,0 & 13,0 & 15,0 & 15,0 & 14,0 & 13,0 \\
\hline 50 & 16,0 & 16,0 & 17,0 & 17,0 & 16,0 & 15,0 \\
\hline 75 & 18,0 & 18,0 & 19,0 & 19,0 & 18,0 & 17,0 \\
\hline 90 & 20,0 & 19,0 & 20,0 & 20,0 & 20,0 & 18,0 \\
\hline 95 & 20,0 & 20,0 & 20,0 & 20,0 & 20,0 & 19,0 \\
\hline \multicolumn{7}{|c|}{ Relationship with parents (4) } \\
\hline
\end{tabular}


Dejana Bouillet: An assessment of primary school pupils' needs with regard to planning the social-pedagogic...

\begin{tabular}{|c|c|c|c|c|c|c|}
\hline Percentiles & Total & $\mathbf{M}$ & $\mathbf{F}$ & 3rd grade & 5 th grade & 7th grade \\
\hline 5 & 17,4 & 17,0 & 18,0 & 18,0 & 18,0 & 16,0 \\
\hline 10 & 19,8 & 19,0 & 20,0 & 20,0 & 20,0 & 18,0 \\
\hline 25 & 23,0 & 22,0 & 23,0 & 24,0 & 23,0 & 21,0 \\
\hline 50 & 26,0 & 26,0 & 26,0 & 26,0 & 26,0 & 24,0 \\
\hline 75 & 28,0 & 28,0 & 28,0 & 28,0 & 28,0 & 27,0 \\
\hline 90 & 30,0 & 30,0 & 29,0 & 30,0 & 30,0 & 29,0 \\
\hline 95 & 30,0 & 30,0 & 30,0 & 30,0 & 30,0 & 30,0 \\
\hline \multicolumn{7}{|c|}{ Level of parental support (5) } \\
\hline Percentiles & Total & $\mathbf{M}$ & $\mathbf{F}$ & 3rd grade & 5 th grade & 7th grade \\
\hline 5 & 9,0 & 8,0 & 10,0 & 8,0 & 9,0 & 8,0 \\
\hline 10 & 11,0 & 10,0 & 12,0 & 11,0 & 11,0 & 11,0 \\
\hline 25 & 13,0 & 13,0 & 14,0 & 14,0 & 14,0 & 13,0 \\
\hline 50 & 16,0 & 16,0 & 17,0 & 16,0 & 17,0 & 16,0 \\
\hline 75 & 19,0 & 18,0 & 19,0 & 19,0 & 19,0 & 18,0 \\
\hline 90 & 20,0 & 20,0 & 20,0 & 20,0 & 20,0 & 20,0 \\
\hline 95 & 20,0 & 20,0 & 20,0 & 20,0 & 20,0 & 20,0 \\
\hline \multicolumn{7}{|c|}{ Openness in communication and interests (6) } \\
\hline Percentiles & Total & M & $\mathbf{F}$ & 3rd grade & 5 th grade & 7th grade \\
\hline 5 & 16,0 & 16,0 & 16,0 & 16,0 & 16,0 & 17,0 \\
\hline 10 & 18,0 & 18,0 & 18,0 & 18,0 & 19,0 & 19,0 \\
\hline 25 & 21,0 & 21,0 & 21,0 & 20,0 & 21,0 & 22,0 \\
\hline 50 & 24,0 & 24,0 & 24,0 & 23,0 & 24,0 & 24,0 \\
\hline 75 & 26,0 & 26,0 & 27,0 & 26,0 & 27,0 & 27,0 \\
\hline 90 & 28,0 & 28,0 & 28,0 & 28,0 & 28,0 & 28,0 \\
\hline 95 & 29,0 & 29,0 & 29,0 & 29,0 & 29,0 & 29,0 \\
\hline \multicolumn{7}{|c|}{ Attitude towards the head teacher (7) } \\
\hline Percentiles & Total & M & $\mathbf{F}$ & 3rd grade & 5 th grade & 7th grade \\
\hline 5 & 11,0 & 10,0 & 12,0 & 12,0 & 12,0 & 9,0 \\
\hline 10 & 12,0 & 12,0 & 13,0 & 13,0 & 13,0 & 11,0 \\
\hline 25 & 14,0 & 14,0 & 15,0 & 15,0 & 15,0 & 13,0 \\
\hline 50 & 17,0 & 16,0 & 17,0 & 17,0 & 17,0 & 16,0 \\
\hline 75 & 18,0 & 18,0 & 19,0 & 19,0 & 19,0 & 18,0 \\
\hline 90 & 20,0 & 19,0 & 20,0 & 20,0 & 20,0 & 19,0 \\
\hline 95 & 20,0 & 20,0 & 20,0 & 20,0 & 20,0 & 20,0 \\
\hline \multicolumn{7}{|c|}{ Attitude to self (8) } \\
\hline Percentiles & Total & M & $\mathbf{F}$ & 3rd grade & 5 th grade & 7th grade \\
\hline 5 & 9,0 & 9,0 & 8,0 & 9,0 & 9,0 & 8,0 \\
\hline 10 & 10,0 & 10,0 & 10,0 & 11,0 & 10,0 & 9,0 \\
\hline 25 & 12,0 & 12,0 & 12,0 & 12,0 & 12,0 & 11,0 \\
\hline 50 & 13,0 & 13,0 & 14,0 & 14,0 & 14,0 & 13,0 \\
\hline 75 & 15,0 & 15,0 & 15,0 & 15,0 & 15,0 & 14,0 \\
\hline 90 & 15,0 & 15,0 & 15,0 & 15,0 & 15,0 & 15,0 \\
\hline
\end{tabular}




\begin{tabular}{|c|c|c|c|c|c|c|}
\hline 95 & 15,0 & 15,0 & 15,0 & 15,0 & 15,0 & 15,0 \\
\hline \multicolumn{7}{|c|}{ Permissiveness in upbringing (9) } \\
\hline Percentiles & Total & $\mathbf{M}$ & $\mathbf{F}$ & 3rd grade & 5 th grade & 7th grade \\
\hline 5 & 6,4 & 6,0 & 7,0 & 7,0 & 7,0 & 6,0 \\
\hline 10 & 8,0 & 8,0 & 8,0 & 8,0 & 8,0 & 7,0 \\
\hline 25 & 10,0 & 9,0 & 10,0 & 10,0 & 10,0 & 9,0 \\
\hline 50 & 12,0 & 11,0 & 12,0 & 12,0 & 12,0 & 11,0 \\
\hline 75 & 13,0 & 13,0 & 14,0 & 14,0 & 14,0 & 13,0 \\
\hline 90 & 15,0 & 15,0 & 15,0 & 15,0 & 15,0 & 14,0 \\
\hline 95 & 15,0 & 15,0 & 15,0 & 15,0 & 15,0 & 15,0 \\
\hline
\end{tabular}

The data displayed in Table 7 point to there being differences among the pupils in the scores that they reach on the factors, based on their age and sex. The differences are the least pronounced on the factor of relationship with peers, and the most pronounced on the factors of attitudes towards education and obligations. This suggests that the sorting of pupils into categories of behavioral difficulties, behavioral disorders, and other, needs to take into account their age and sex. For the needs of this study, the groups were formed based on the pupils' grade, as the F-ratios determined the pupils' grade qualitatively discriminates the respondents by age (F-ration $=20940.125, p=.000)$. The results reached in analysis of thusly formed groups are presented in Table 8.

Table 8 Distribution of respondents by the extent to which they manifest behavioral problems, values and significance of the t-test and Pearson correlation of groups with the independently determined criterion of behavioral problems

\begin{tabular}{|c|c|c|c|c|c|c|c|}
\hline Factor & $\begin{array}{c}\text { Pupils } \\
\text { with } \\
\text { behavioral } \\
\text { disorders }\end{array}$ & $\begin{array}{c}\text { Pupils } \\
\text { with } \\
\text { behavioral } \\
\text { difficulties }\end{array}$ & $\begin{array}{l}\text { All pupils with } \\
\text { some form } \\
\text { of behavioral } \\
\text { problems }\end{array}$ & T-test & $\mathbf{p}$ & $\begin{array}{c}\text { Pearson } \\
\text { coeff. }\end{array}$ & $\mathbf{p}$ \\
\hline Relationship with peers (1) & 5,6 & 5,4 & 11,0 & 49,416 & 000 &, 069 &, 000 \\
\hline Attitude towards education (2) & 7,4 & 4,9 & 12,3 & 215,277 & 000 &, 147 &, 000 \\
\hline Attitude towards obligations (3) & 6,3 & 7,1 & 13,4 & 14,274 & 000 &, 036 &, 040 \\
\hline Relationship with parents (4) & 7,0 & 4,4 & 11,4 & 107,035 & 000 &, 100 &, 000 \\
\hline Level of parental support (5) & 4,9 & 7,5 & 12,5 & 35,491 & 000 &, 055 &, 002 \\
\hline Openness in communication and interests (6) & 7,0 & 7,9 & 15,0 & 59,103 & 000 & 071 &, 000 \\
\hline Attitude towards the head teacher (7) & 7,9 & 5,6 & 13,5 & 53,858 & 000 & ,068 &, 000 \\
\hline Attitude to self (8) & 6,7 & 8,7 & 15,4 & 127,346 &, 000 &, 115 &, 000 \\
\hline Permissiveness in upbringing (9) & 7,1 & 4,3 & 11,4 & 37,709 & ,000 & ,058 & ,001 \\
\hline
\end{tabular}

Looking into the results from Table 8 allows us to conclude that the behavioral difficulties and disorders are manifested by $12.88 \%$ of pupils in our sample, which could be considered the proportion of pupils with behavioral difficulties in the primary school population in Croatia (given the structure of the sample that includes both the younger and older pupils). The model of the displayed distribution of pupils has been confirmed through a two-step cluster analysis that resulted in a good level of cohesion and separation of the groups of pupils on the criterion of manifestation of behavioral problems (Image 1). 
Model Summary

\begin{tabular}{|c|c|}
\hline Algorithm & TwoStep \\
\hline Inputs & 9 \\
\hline Clusters & 2 \\
\hline
\end{tabular}

Cluster Quality

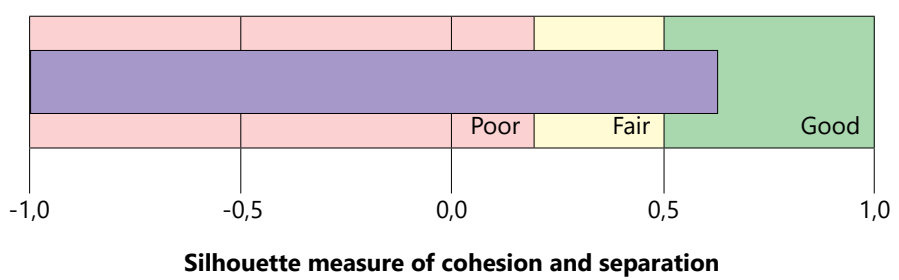

Image 1: Level of cohesion and separation of the groups of pupils on the criterion of manifestation of behavioral problems

This indicates that the planning of inclusion of pupils in social-pedagogic interventions and planning of the content of these intervention should be guided by the criteria displayed in Table 9 , by linking the content of interventions with the expressed needs of the pupils. Additionally and when appropriate, the intervention should also include other experts, such as psychologists, educational rehabilitators, logopedists, social workers, physicians. The intervention thus could and should (and often it does) aim to encompass the areas of relationships with peers, openness in communication and interests, attitude towards the head teacher, family relations. Similarly, peer assistance and mentoring programmes could act to improve the areas of attitude towards education, attitude towards obligations, attitude to self, and relationships with peers.

Table 9 Criteria for inclusion of pupils in groups with behavioral difficulties, and planning of intervention as expressed by the points on the Pupils' Needs in the Area of Social-Pedagogic Intervention Questionnaire - Pupils' Version

\begin{tabular}{|l|c|c|c|c|c|c|}
\cline { 2 - 6 } \multicolumn{2}{c|}{} & \multicolumn{2}{c|}{ 3rd grade } & \multicolumn{2}{c|}{ 5th grade } & \multicolumn{2}{c|}{ 7th grade } \\
\hline Factor & $\begin{array}{c}\text { Pupils with } \\
\text { behavioral } \\
\text { disorders }\end{array}$ & $\begin{array}{c}\text { Pupils with } \\
\text { behavioral } \\
\text { difficulties }\end{array}$ & $\begin{array}{c}\text { Pupils with } \\
\text { behavioral } \\
\text { disorders }\end{array}$ & $\begin{array}{c}\text { Pupils with } \\
\text { behavioral } \\
\text { difficulties }\end{array}$ & $\begin{array}{c}\text { Pupils with } \\
\text { behavioral } \\
\text { disorders }\end{array}$ & $\begin{array}{c}\text { Pupils with } \\
\text { behavioral } \\
\text { difficulties }\end{array}$ \\
\hline Relationship with peers (1) & $0-21$ & $22-24$ & $0-21$ & $22-24$ & $0-21$ & $22-23$ \\
\hline Attitude towards education (2) & $0-16$ & 17 & $0-14$ & $15-16$ & $0-12$ & 13 \\
\hline Attitudes towards obligations (3) & $0-10$ & $11-12$ & $0-11$ & 12 & $0-9$ \\
\hline Relationship with parents (4) & $0-18$ & $19-20$ & $0-18$ & $19-20$ & $0-16$ & $17-18$ \\
\hline Level of parental support (5) & $0-8$ & $9-11$ & $0-9$ & $10-11$ & $0-8$ \\
\hline $\begin{array}{l}\text { Openness in communication and } \\
\text { interests (6) }\end{array}$ & $0-16$ & $17-18$ & $0-16$ & $17-19$ & $9-11$ \\
\hline $\begin{array}{l}\text { Attitude towards the head teacher } \\
\text { (7) }\end{array}$ & $0-12$ & 13 & $0-12$ & 13 & $18-19$ \\
\hline Attitude towards self (8) & $0-9$ & $10-11$ & $0-9$ & 10 & $0-9$ \\
\hline Permissiveness in upbringing (9) & $0-7$ & 8 & $0-7$ & 8 & $10-11$ \\
\hline
\end{tabular}




\begin{tabular}{|l|l|l|l|l|l|l|}
\hline Total score (out of 210) & 117 & 134 & 117 & 133 & 106 & 112 \\
\hline
\end{tabular}

Since the results of the Questionnaire also depend on the pupils' sex (Table 7), the rules in Table 9 should also be interpreted with regard to that criterion. Table 10 displays the directions in which the pupil's sex can be reflected in group placement.

Table 10 The impact of sex on the placement of pupils into the groups with regard to behavioral difficulties and planning of intervention, as expressed in the points on the Pupils' Needs in the Area of Social-Pedagogic Intervention Questionnaire - Pupils' Version

\begin{tabular}{|l|c|c|c|c|c|c|}
\cline { 2 - 6 } \multicolumn{1}{c|}{} & \multicolumn{2}{c|}{ 3rd grade } & \multicolumn{2}{c|}{ 5th grade } & 7th grade \\
\hline Factor & $\mathbf{M i}$ & $\mathbf{F}$ & $\mathbf{M}$ & $\mathbf{F}$ & - & - \\
\hline Relationships with peers (1) & - & - & - & - & +1 point & +2 points \\
\hline Attitude towards education (2) & -3 points & -2 points & -1 point & - & - & +2 points \\
\hline Attitude towards obligations (3) & -2 points & +1 point & -1 point & - & +1 point & +2 points \\
\hline Relationship with parents (4) & -1 point & - & - & - & - & +2 points \\
\hline Level of parental support (5) & - & +2 points & -1 point & +2 points & -1 point & -1 point \\
\hline Openness in relationships (6) & - & - & - & - & +1 point & +3 points \\
\hline Attitude towards head teacher (7) & -2 points & - & -2 points & - & - \\
\hline Attitude to self (8) & - & -1 point & - & -1 point & - \\
\hline Educational styles (9) & -1 point & - & -1 point & - & - & +1 point \\
\hline Total difference & $\mathbf{9}$ & $\mathbf{0}$ & $\mathbf{6}$ & $\mathbf{1}$ & $\mathbf{2}$ & $\mathbf{1 1}$ \\
\hline
\end{tabular}

Based on the results in Table 9, we suggest that the pupils' sex and age should be used to interpret their results on the Questionnaire when social-pedagogic interventions are considered. The boundary for behavioral problems among the pupils in the third grade is expanded by 9 points for boys, and stays the same for girls. When it comes to pupils in the fifth grade, the boundary is expanded by 6 points for boys, and 1 point for girls. Among the seventh-graders, the boundary for boys is expanded by 2 points, and by 11 points for girls.

It should be pointed out that these rules are a work in progress, and will be further tested in the next stage of the project, on a sample of pupils with behavioral problems in schools that will be implementing and evaluating the social-pedagogic interventions based on the Pupils' Needs in the Area of Social-Pedagogic Intervention Questionnaire - Pupils' Version.

\section{Discussion and conclusion}

This paper has presented a part of the research conducted as part of the Development of the Models of Social-Pedagogic Interventions in Primary School project that has been conducted since September 2015 with the support of Croatia's Education and Teacher Training Agency. The paper's focus is on the development of a measurement instrument for timely identification of behavioral problems among primary school pupils, based on pupils' self-assessment, and in order to ensure the following preconditions for evaluating the social-pedagogic interventions in the school environment: (a) a standardized procedure for identifying the pupils who are having behavioral difficulties and (b) determining the pupils' needs in the area of social-pedagogic intervention. According to our results, the initial conditions for the standardization of the process of identifying 
the pupils with behavioral problems have been created, as reflected in the creation of the Pupils' Needs in the Area of Social-Pedagogic Intervention Questionnaire - Pupils' Version, which has been found to appropriately differentiate between pupils who have behavioral difficulties, and those who do not. It has also been confirmed that grouping pupils by the extent of their behavioral difficulties is dependent on their sex and age. However, the Questionnaire has been standardized on a sample of primary school pupils, and its further application in schools will likely contribute to new findings and potentially lead to new and altered versions of this initial version of the Questionnaire. For this reason, it is important to further develop the identification rules established in this study, particularly when one bears in mind the need to apply the Questionnaire across all age groups.

It is very important to bear in mind that this Questionnaire is an assistive tool in planning social-pedagogic interventions and could not possibly replace the usual procedures of social-pedagogic assessment of the pupils' needs and problems. However, its application can significantly enhance the work of the social pedagogues in schools, as the score on the Questionnaire provides a wide range of information regarding a pupil's intervention needs, with regard to all areas of social-pedagogic activity. These areas are peer relationships, education, work habits, family relationships (including the assessment of styles of upbringing exhibited by both the parents and the teachers), attitude towards authority, self-image, and social skills. The Questionnaire applied in this study measures the pupil's attitude towards the head teacher, as we aimed to have specific information regarding who the pupil is assessing, but this section of items could easily refer to any of the teachers, based on the relevant case.

With regard to the proportion of pupils with behavioral difficulties, the initial $14.4 \%$ identified by the social pedagogues as such has been reduced in our statistical analyses to $12.9 \%$. This difference of $1.5 \%$ is partly a consequence of the circumstances, as a portion of the pupils in the former group is that which exhibits risk behaviors, and it may have also been the result of the manner in which the cutoff points for the groups with different levels of behavioral difficulties were set in this study. Further, this may also be related to the fact that the results of this study come from pupils' self-assessment, as we know from the literature that the pupils tend to be more restrictive in their assessments of behaviors when compared to the assessments of their problems and needs that are provided by others (Bouillet, 2015b, Pevin Ivanec, 2015).

Grouping pupils based on the extent to which they exhibit behavioral difficulties was conducted in this study according to the pupils' grade, while a parallel process based on sex will be conducted in the latter stages of the project. Nevertheless, the hypothesis of expecting the proportion of pupils with behavioral difficulties to be around the same as was found in previous studies (i.e. 15\%) has been confirmed, suggesting that the developed measurement instrument is valid, objective, and reliable.

\section{References}

Abu-Rayya, H.M., Yang, B. (2012): Emotional and Behavioral Problems and Their Underlying Risk Factors Among Children in New South Wales. International Journal of Mental Health, 41(3). 3-23.

Barnett, W.S. (2011): Effectiveness of Early Educational Intervention. Science, 333(19). 975-978. 
Bouillet, D. (2011): Socijalnopedagoška praksa i potrebe korisnika [Social-pedagogic practice and the users' needs], U: Poldrugač, Z., Bouillet, D., Ricijaš, N. (ur.): Socijalna pedagogija: znanost, profesija i praksa u Hrvatskoj [Social pedagogy: science, profession, and practice in Croatia], Zagreb: Edukacijsko-rehabilitacijski fakultet Sveučilišta u Zagrebu, 131-151.

Bouillet, D., (2015a): Konceptualni okvir razvoja modela rane odgojno-obrazovne intervencije [The conceptual framework of the development of models for early educational intervention]. U: Bouillet, D. (ur.): Razvoj modela rane odgojno-obrazovne intervencije u osnovnoj školi: od ideje do evaluacije [Development of models for early educational intervention in primary school: from idea to evaluation], Zagreb: Forum za slobodu odgoja. 25-47.

Bouillet, D. (2015b): Procjena i samoprocjena problema u ponašanju učenika razredne nastave: prilike i izazovi [Assessment and self-assessment of behavioural problems of primary school pupils: opportunities and challenges]. Kriminologija i socijalna integracija, 22(1). 105-128, http://hrcak.srce.hr/132684

Boydell Brauner, Ch., Bowers Stephans, Ch. (2006): Estimating the Prevalence of Early Childhood Serious Emotional/Behavioral Disorders: Challenges and Recommendations, Public Health Report, 121(3). 303-310.

Conley, L., Marchant, M., Caldarella, P. (2014): A comparison of teacher perceptions and research-based categories of student behavior difficulties. Education, 134(4). 439450.

Conroy, M.A., Brown, W.H. (2004): Early Identification, Prevention, and Early Intervention with Young Children At Risk for Emotional or Behavioral Disorders: Issues, Trends, and a Call for Action. Behavioural Disorders, 29(3). 224-236.

Eklund, K., Renshaw, T.L., Dowdy, E., Jimerson, Sh.R., Hart, Sh.R., Jones, C.N., Earhart, J. (2009): Early Identification of Behavioral and Emotional Problems in Youth: Universal Screening versus Teacher-Referral Identification. The California School Psychologist, 14. 89-95.

Gable, R.A. (2004): Hard Times and an Uncertain Future: Issues that Confront the Field of Emotional/Behavioral Disorders. Education and Treatment of Children, 27(4). 341 352.

George, D., Mallery, M. (2010): SPSS for Windows Step by Step: A Simple Guide and Reference. Boston: Pearson.

Koller-Trbović, N., Mirosavljević, A., Jeđud Borić, I. (2013): Procjena intervencijskih potreba djece i mladih s problemima u ponašanju [Assessment of intervention needs of the children and youths with behavioral problems]. U: Žižak, A., Koller-Trbović, N., ur.: Procjena rizika i snaga u funkciji planiranja tretmana: Rezultati znanstvenog projekta: Usklađivanje intervencija s potrebama djece i mladih u riziku: izrada modela [Risks and strenghts assessment aimed for treatment planning (Results of scientific project: Matching interventions with needs of children at risk-creating a model]. Zagreb: Edukacijsko-rehabilitacijski fakultet Sveučilišta u Zagrebu, 23-66.

Koller-Trbović, N., Nikolić, B., Dugandžić, V. (2009): Procjena čimbenika rizika kod djece i mladih u riziku ili s poremećajima u ponašanju [Assessment of risk factors in children and youth in risk or with behaviour disorders in different intervention systems: socioecological model]. Hrvatska revija za rehabilitacijska istraživanja, 45(2). 37-54. 
Koller-Trbović, N., Žižak, A. (2012): Problemi u ponašanju djece i mladih i odgovori društva: višestruke perspektive [Children and youth with behavioral problems: the multiple perspectives approach]. Kriminologija i socijalna integracija, 20(1). 49-62.

Koller-Trbović, N., Žižak, A., Jeđud Borić, I. (2011): Standardi za terminologiju, definiciju, kriterije i način praćenja pojave poremećaja u ponašanju djece i mladih [Standards for Terminology, Definition, Criteria and Follow up of Behaviour Disorders in Children and Youth]. Zagreb: Ministarstvo obitelji, branitelja i međugeneracijske solidarnosti.

Konvencija o pravima djeteta [Convention on the Rights of the Child] (1990.). Službeni list Međunarodni ugovori 15/90. Narodne novine - Međunarodni ugovori 12/93. 20/97.

Kyriacou, Ch. (2009): The five dimensions of social pedagogy within schools. Pastoral Care in Education, 27(2). 101-108.

Kyriacou, Ch., Tollisen Ellingsen, I., Stephens, P., Sundaram, V. (2009): Social pedagogy and the teacher: England and Norway compared. Culture \& Society, 17(1). 75-87.

Okvir za poticanje i prilagodbu iskustva učenja te vrednovanje postignuća djece i učenika s teškoćama [Framework for encouraging and adjusting the experience of learning, and the assessment of children and pupils experiencing difficulties](2016), prijedlog Nacionalnog dokumenta. http://www.kurikulum.hr/wp-content/uploads/2016/02/ Okvir-djeca-i-ucenici-s-teskocama.pdf (Retrieved 29.8.2016.)

Pastor, P.N., Reuber, C.A, Duran, C.R. (2012): Identifying Emotional and Behavioral Problems in Children Aged 4-17 Years: United States, 2011-2007. National Health Statistics Reports. Number 48." National Center for Health Statistics.

Pavin Ivanec, T. (2015): Potrebe učenika za ranom odgojno-obrazovnom intervencijom: fenomenologija i rasprostranjenost problema u ponašanju [The need for early educational intervention: phenomenology and incidence of behavioural disorders]. U: Bouillet, D. (ur.): Razvoj modela rane odgojno-obrazovne intervencije u osnovnoj školi: od ideje do evaluacije [Development of the model of early educational intervention in primary school: from idea to evaluation], Zagreb, Forum za slobodu odgoja. 33-47.

Smith, M., Whyte, B. (2008): Social education and social pedagogy: reclaiming a Scottish tradition in social work. European Journal of Social Work, 11(1). 15-28.

Statističko priopćenje: Osnovno škole - kraj šk. god. 2014./2015. i početak šk. god. 2015./2016

[Statistical Bulletin: Primary Schools at the end of the 2014/2015 and beginning of 2015/2016 school year]. Državni zavod za statistiku, www.dzs. hr (Retrieved 25.8.2016.)

Stevens, I. (2010): Social Pedagogy and its links to Holding the Space. Glasgow: Scottish Institute for Residential Child Care - SIRCC.

Storø, J. /2013): Practical Social Pedagogy: Theories, values and tools for working with children and young people. Bristol, The Policy Press.

Strategija obrazovanja, znanosti i tehnologije [Strategy for education, science and technology]. Narodne novine 124/14.

Tabachnick, B.G., Fidell, L.S. (2001): Using Multivariate Statistics. Boston: Allyn and Bacon.

Žižak, A. (2010): Teorijske osnove intervencija - socijalnopedagoška perspektiva [Theoretical basis of intervention - a social-pedagogic perspective]. Zagreb: Edukacijskorehabilitacijski fakultet Sveučilišta u Zagrebu. 
Dejana Bouillet: An assessment of primary school pupils' needs with regard to planning the social-pedagogic...

Žižak, A., Koller-Trbović, N., ur (2013): Procjena rizika i snaga u funkciji planiranja tretmana: Rezultati znanstvenog projekta: Usklađivanje intervencija s potrebama djece i mladih u riziku: izrada modela [Risks and strenghts assessment aimed for treatment planning (Results of scientific project: Matching interventions with needs of children at risk- creating a model]. Zagreb: Edukacijsko-rehabilitacijski fakultet Sveučilišta u Zagrebu. 